\title{
Building resilience for stronger communities
}

\author{
Barbara S. Gainey \\ Kennesaw State University \\ Kennesaw, Georgia, USA
}

\begin{abstract}
Much of the early research in crisis management and crisis communication centered on the core competencies of crisis response: why do we need to plan for crises; what are the stages of effective crisis planning; what theoretical perspectives are helpful to scholars and practitioners; and what are the steps of an up-to-date crisis plan. Delineation of these core competencies goes on. Among these competencies, the crisis stage meriting the least attention arguably is postcrisis, the critical days and weeks immediately following the formal resolution of the crisis. Research attention has often focused on recovery and learning, positioning the organization for the future. Another critical component of effective crisis response merits further study. In these days of black swan crises that take a huge toll on organizations and their communities, more focus is needed on building individual, organizational, and community resilience to destructive crises. While resilience can be best measured in the post-crisis phase, this assessment should lead to new efforts to educate and prepare individuals, organizations, and communities for the new threats to come. This research proposes strategies for building resilience to strengthen organizational and community response when confronted by major crisis events.
\end{abstract}

Keywords - crisis management, crisis leadership, crisis communication, crisis response, resilience

SUGGESTED CITATION: Gainey, B. S. (2020). Building resilience for stronger communities. Proceedings of the International Crisis and Risk Communication Conference, Volume 3 (pp. 37-40). Orlando FL: Nicholson School of Communication and Media. https://www.doi.org/10.30658/icrcc.2020.9

\section{INTRODUCTION}

Bruce Schneier, a fellow and lecturer at Harvard Kennedy School, wrote in 2019 what now seems a prophetic opinion piece in The New York Times, regarding future black swan health crises. On June 17, 2019, Schneier advocates preparing for a new pandemic on two fronts, with the first being understanding the new disease, while looking for a vaccine and a cure. The second front would be fought online, responding to rumors, misinformation and "flat-out lies" that appear in social media and other Internet sites [1].

That is exactly the position we find ourselves in with the 2020 outbreak of the coronavirus and the confusion about the methods of transmission, fatality rates, accurate testing for the virus (in the United States and globally), and concerns about impacts on financial markets leading to the outbreak becoming a political and social-media hot potato [2]. Pick a news site, any news site, and you will find the latest musings about the state of this international health emergency. No one is sure what is coming next and if the medical community, economies, and countries have the capacity for an effective long-term response. The threat of this new pandemic is testing, among other things, plans for resilient individuals, communities, and societies. This paper will explore the current state of building resiliency as part of a crisis preparation and response plan and the role crisis leadership plays in promoting resiliency in the face of crisis.

\section{CHANGING PREPARATION FOR CRISIS}

Traditional crisis preparation best practices address the appropriate steps that should be taken in pre-crisis, or before a crisis occurs; after the triggering event of the crisis and during the life cycle of the crisis; and the post-crisis stage, when the organization or community move beyond the crisis to the new reality. We have moved from an era focused on business-related crises (Extra-Strength Tylenol, Exxon Valdez) to natural disasters (Hurricanes Katrina and Sandy, earthquakes and tsunamis in Japan, wildfires in California and Australia) to global concerns about terrorism, mass shootings and other forms of violence, and pandemics. Creating a comprehensive listing of current crises would be difficult, as cybersecurity and other threats continue to evolve.

As Boin [3] noted in 2009, "The shape and dynamics of crises and disasters is changing. They have different causes, play out differently, draw different reactions, and affect societies in different ways" [p. 367]. Boin proposed that crises of

ISSN: 2576-9111

(C) 2020 Copyright is held by owner/author(s).

Publication rights are licensed to ICRCC.

https://doi.org/10.30658/icrcr.2020.9 
the future would be "transboundary" in nature, crossing geographical borders, functional or sector boundaries (from industrial to the financial sector, for example), political borders, or time or generational constructs [p. 367]. Crisis literature benefits from the multidisciplinary nature of crisis preparation, including communication, psychology, business, economics, health, and sociology. In addition to the benefits of research from multiple disciplines that provide data-based guidance to organizations and individuals, there is also the need for communities to develop their own strategies for preparedness and resilience [4].

Numerous researchers have pointed to concerns about organizations and societies not being properly prepared to respond to modern crises for a multitude of reasons; these reasons may include an organization not being a good learner from past experiences, being unwilling to take mitigation steps for something that might not occur, or a lack of mechanisms to recognize and make sense of a rapidly developing crisis [3]. There is still an inclination to think of a crisis as being the rare exception rather than an anticipated event or occurrence given the interconnectedness of a global society and the speed of communication. Lagadec wrote in 2009 that "our whole philosophy of risk and crisis is that the event is clearly specific, isolated, independent, and above all, very limited compared to the size of the systems affected" [5, p. 474]. That clearly is no longer true. As Lagadec said, "No ready-made answer can be the solution to modern crises" [5, p. 478].

Modern crises tend to affect large populations, have high economic costs, create communication challenges and uncertainties, and snowball into other dilemmas [6]. In addition, public leaders no longer have a monopoly on framing a crisis [7]; today's crisis leaders have competition from 24/7 news organizations, social media, and individual influencers whose podcasts or blogs may not be differentiated from a post from the Centers for Disease Control and Prevention or other scientific authority. The challenges of responding to a global challenge were played out in 2020 through the COVID-19 pandemic that occupied the real and virtual pages of mass media, social media, and communication between family and friends. As scholars analyse this evolving pandemic, we will see just-in-time studies of crisis preparation and response, providing more evidence of the role of resilience in building stronger communities, ready to face new threats and opportunities.

\section{RESILIENCE AS PART OF CRISIS MANAGEMENT}

Resilience may be observed as a crisis unfolds and is resolved, but the groundwork for resilience must be laid before a crisis is evident. Norris et al. [8, p. 130] defines resilience as "a process linking a set of adaptive capabilities to a positive trajectory of function and adaptation after a disturbance." This research will discuss what those "adaptive capabilities" may include in order to build an individual's or community's ability to maintain a stable equilibrium or positive relationships throughout the crisis [8]. Capacities at different levels of society (individual, community, national, or global) are often linked to a sense of well-being, health and safety, connections between individuals and community organizations, an alignment in sense of purpose, a measure of social trust, and recognition of shared interests, and collaboration between individuals, various levels of government, business, and society [9].

Indicators of resilience can help in "navigating this new era of high uncertainly and low controllability" [10, p.4]. These principles include recognizing constant change and the ability to adapt to stress and risk; inclusive decisionmaking, empowering often marginalized groups; promoting adaptive approaches and learning what works; and leveraging innovation to build resilience [11].

At its base level, resilience is a component of the individual's response to a traumatic or crisis event. Resilient individuals demonstrate an adaptive capability of self-efficacy or the belief in one's ability to protect one's self and one's family [12]. The individual believes he or she can find the information needed for protection and safety and can depend on a support system that may include neighbors and the community. The resilient individual exhibits personality traits such as optimism and trust, has secure and stable relationships, is flexible in the face of crisis, and exhibits problemsolving skills and the trait of hardiness [13]. Hardiness has been defined as the belief that one can influence the outcome of events and learn and grow from a traumatic or crisis experience [14]. Strong role models can help promote resiliency in the midst of the crisis [13]. Promoting a sense of togetherness, an "everyone has skin in the game" approach, can support resiliency. Helping individuals cope by identifying with a greater community (such as evidenced in the slogans of "Boston Strong" after the Boston marathon bombing of 2013 and "the Volunteer State" after the Nashville, Tennessee, spring 2020 tornadoes) encourages resiliency, as does sharing narratives and stories of crisis experiences through social media and other outlets [12]. Individual resiliency is supported by trustworthy leaders and the existence of common community values [15].

Resilience is also a factor in a community's collective response to a disaster or other upheaval. The "ability of communities to withstand external shocks to their social infrastructure" and to recover illustrates a capacity to provide a buffer between the community and the crisis is has confronted [16 p. 361]. That sense of community must be developed before the crisis. Community resilience can be supported by connections between people, between people and community organizations, and by local and responsible media [16]. Having attachments to place (such as places of work, worship, or recreation), economic stability, trusted sources of information, and political partnerships are contributing factors to community resilience. A sense of empowerment (versus powerlessness) and a sense of the fairness in the distribution of risk or vulnerability to the crisis are also important [16]. 
Societal resilience is based on the capacities demonstrated at individual and community levels [12]. Societal resilience can be promoted through positive strategies such as the creation of shelters to protect citizens, first aid, and other resources or services. Coordinated planning and the delivery of interventions with a sense of urgency and interdependency also strengthens societal resilience [12].

\section{DEVELOPING LEADERSHIP FOR BUILDING RESILIENCE}

Challenges for communities and organizations alike is the need to develop leaders who can build resilience in those within their spheres of influence. As the leadership traits are examined in the literature, they are often similar to other traits found in exceptional crisis leaders: more creative than procedural; innovative and adept to take the initiative; skilled at coordinating the flow of information, resources and expertise; able to articulate a clear mission and make sense of the impending crisis; clarity in articulating purpose and sense of urgency in responding to the crisis; ability to inspire confidence and trust; and ability to identify a path to a successful response and resolution of the crisis. "Understanding the communication values that leaders possess precrisis can predict the types of crisis communication that leaders will produce and ultimately the trajectory of the crisis" [4, p. 531].

Modern crises call for leaders who can determine resource needs and partner with others to expand capacity to create those resources, whether they be basic supplies (food, water, infrastructure, safety) or more long-term solutions (technology, health and medical, or mass production). Leaders must work around existing gaps and create critical alignments among the layers of business, NGOs, and government. On-the-ground responders must be empowered to act to protect life and property. Emotional and intuitive intelligence are other key attributes of crisis leaders [17].

Communities are confronting crises that often are far-reaching, with broader and longer-lasting impacts, than isolated crises of the past. The black swan crisis, of low-probability but high-impact events, is more likely to be a defining characteristic of the modern era. "A critical issue for scholars of crisis management is to determine how to get organizations, societies, and their citizens to prepare for crises" [4, p. 533]. Part of this preparation is an underpinning of resilience to be ready to face atypical crises. The Homeland Security Report, "Crisis Response and Disaster Resilience 2030: Forging Strategic Action in an Age of Uncertainty (2012)" points to the need to empower individuals with more responsibility, support innovative "boots on the ground" approaches to societal crisis and risk, and develop new models and tools of effective crisis response [18]. This "boots on the ground" approach requires that we help build resilience into our communities and their citizens so they can adapt to whatever the future may throw at them.

During the California wildfires of November 2019, Shannon Stirone wrote an opinion piece for The New York Times about real life resembling the disaster films that many grew up watching. Much of what she wrote could be replicated for the corona virus pandemic of 2020: store shelves gutted, schools closed, walkers in face masks, and residents going without pay [19]. She said "Maybe now....more of us will listen to calls for...radical reforms." Diana Leonard, writing in The Washington Post about the Australian fires in January 2020, said "lessons from the past might not be enough to guard against future disasters" and we needed to plan for crisis events "that have no historical analogue" [20]. Clearly, now is the time to equip citizens with the resilience to withstand evolving crises in the hope of returning to that dreamed of state of normalcy. "Normality is our natural nest, stability our beloved home and certainty our paramount aspiration" [21, p. 4]. Preparing resilient citizens is as crucial to normality as responding to the intricacies and demands of the next crisis.

\section{Author Biography}

Barbara S. Gainey, Ph.D. from the University of South Carolina; Kennesaw State University, bgainey@kennesaw.edu

\section{REFERENCES}

[1] Schneier, B. We must prepare for the next pandemic. (2019). The New York Times, 6/17. Retrieved from https:///www.nytimes.com/2019/06/17/opinion/pandemic-fake-news.html

[2] Richtel, M. 2020. W.H.O. fights a pandemic besides coronavirus: an 'infodemic.' The New York Times, 2/6. Retrieved from https://www.nytimes.com/2020/02/06/health/coronovirus-misinformation-social-media.html

[3] Boin, A. (2009). The new world of crises and crisis management: Implications for policymaking and research. Review of Policy Research, 26, 367-377. https://doi.org/10.1111/j.1541-1338.2009.00389.x

[4] Ulmer, R. R. (2012). Increasing the impact of thought leadership in crisis management. Management Communication Quarterly, 26, 523-542. https://doi.org/10.1177/08933118912461907

[5] Lagadec, P. (2009). A new cosmology of risks and crises: Time for a radical shift in paradigm and practice. Review of Policy Research, 26, 473-486. https://doi.org/10.1111/j.1541-1338.2009.00396.x

[6] Boin, A. \& Lagadec, P. (2000). Preparing for the future: Critical challenges in crisis management. Journal of Contingencies and Crisis Management, 8, 185-191. https://doi.org/10.1111/1468-5973.00138 
[7] Ansell, C., Boin, A. \& Keller, A. (2010). Managing transboundary crises: Identifying the building blocks of an effective response system. Journal of Contingencies and Crisis Management, 18, 195-207. https://doi.org/10.1111/j.14685973.2010.00620.x

[8] Norris, F. H., Stevens, S. P., Pfefferbaum, B., Wyche, K. F., \& Pfefferbaum, R. L. (2007). Community resilience as a metaphor, theory, set of capacities, and strategy for disaster readiness. American Journal of Psychology, 41, 127-150. https://doi.org/10.1007/s10464-007-9156-6

[9] Duckers, M. L. A. (2017). A multilayered psychosocial resilience framework and its implications for community-focused crisis management. Journal of Contingencies and Crisis Management, 25, 182-187. https://doi.org/10.1111/14685973.12183

[10] Matthews, N. (2020). The rise of resilience in a new era. Traumatology, 1/2. http://dx.doi.org/10.1037/trm0000235

[11] Global Resilience Partnership. (2019). Resilience insights: Lessons from the global resilience parnership. Stockholm, Sweden. Retrieved from https://www.globalresiliencepartnership.org/InsightsReport

[12] Zhang, X. A., and Shay, R. (2019). An examination of antecedents to perceived community resilience in disaster postcrisis communication. Journalism \& Mass Communication Quarterly, 96, 264-287. https://doi.org/10.1177/1077699018793612

[13] Almedom, A. M. (2005). Resilience, hardiness, sense of coherence, and postraumatic growth: All pathes leading to "Light at the end of the tunnel"? Journal of Loss and Trauma, 10, 253-265. https://doi.org/10.1080/15325020590928216

[14] Bonanno, G. A. (2004). Loss, travma, and human resilience. American Psychologist, 59, $20-28$. https://doi.org/10.1037/0003-066X.59.1.20

[15] Ulmer, R. R., Seeger, M. W. \& Sellnow, T. L. (2007). Post-crisis communication and renewal: Expanding the parameters of post-crisis discourse. Public Relations Review, 33, 130-134. https://dio.org/10.1016/j.pubrev.2006.11.015

[16] Adger, W. F. (2000). Social and ecological resilience: Are they related? Progress in Human Georgraphy, 24, $347-364$. http://doi.org/10.1191/030913200701540465

[17] Bacon, B. (2013). Intuitive intelligence in leadership. Management Services, 26-29.

[18] “Crisis response and disaster resilience 2030: Forging Strategic Action in an age of uncertainty.” January 2012. FEMA, U.S. Department of Homeland Security.

[19] Stirone, S. (2019). We're living act 1 of the disaster films we grew up with. The New York Times, 11/8. Retrieved from https://www.nytimes.com/2019/11/08/opinion/california-fires-aftermath.html

[20] Leonard, D. (2020). Too late to leave: Australia's advice for surviving a bush fire when surrounded. The Washington Post, January 9 .

[21] Topper, B. And Lagadec, B. (2013). Fractal Crises - A new parth for crisis theory and management, Journal of Contingencies and Crisis Management, 21(1), 4-16. https://doi.org/10.11111/1468-5973.12008 